\title{
THE MARGINALISATION OF MALAYSIAN TEXTS IN THE ENGLISH LANGUAGE CURRICULUM AND ITS IMPACT ON SOCIAL COHESION IN MALAYSIAN CLASSROOMS
}

\author{
Shanthini Pillai", P. Shobha Menon and Ravichandran Vengadasamy
}

School of Language Studies and Linguistics, Faculty of Social Sciences and Humanities, Universiti Kebangsaan Malaysia, MALAYSIA

"Corresponding author: spillai@ukm.edu.my/spillai2900@gmail.com

To cite this article: Shanthini Pillai, P. Shobha Menon and Ravichandran Vengadasamy. 2016. The marginalisation of Malaysian texts in the English language curriculum and its impact on social cohesion in Malaysian classrooms. Kajian Malaysia 34(2): 25-58. http://dx.doi.org/10.21315/ $\mathrm{km} 2016.34 .2 .2$

To link to this article: http://dx.doi.org/10.21315/ km2016.34.2.2

\begin{abstract}
In this paper, we seek to investigate the place that local literature has been given in Malaysian Education in the English Language Subject for Secondary Schools in Malaysia. We argue that literature engenders a space for the nation to share in the experiences and feelings of groups and situations that might never be encountered directly. It often engages with the realities of a nation through diverse constructions of its history, its realities and communal relations. As such we posit that literature can be a significant tool to study the realities of Malaysian nationhood and its constructions of inter-ethnic relationships, and ultimately, an effective tool to forge nation building. The discussion focuses on investigating the role that literature has played in Malaysian education in the context of engaging with ethnically diverse Malaysian learners and whether text selection has prioritised ethnic diversity in its Malaysian context. Samples used for discussion centre on literature in English in Malaysian Education. The paper concludes that more attention needs to be paid to the inclusion of local literature as it can be an important communicator of signifiers of ethnic identity and subsequently play an important role in facilitating inter-ethnic engagement and understanding in Malaysian schools.
\end{abstract}

Keywords: social cohesion, Malaysian literature in English, inter-ethnic engagement, literature text selection, role of literature 


\section{INTRODUCTION}

This article explores the role that literature can play in Malaysian education, in terms of engaging with ethnically diverse Malaysian learners and specifically focuses on investigating the extent to which text selection has prioritised ethnic diversity in its Malaysian context. The discussion centres on the English Language Curriculum in Malaysian Education and its attendant Literature in English component. It does this with the rationale that out of the many languages of creative expression in Malaysia, local works produced in English are by far more predominantly multi-ethnic than those produced in Malay, Tamil, Mandarin and other languages.

We begin with a provision of the historical background of Literature in English in Malaysian Education with an eye towards establishing the extent of the inclusion of local Literature in English. We then move on to present the findings of a case study of the Malaysian Literature in English texts in the three most recent cycles of texts selected for use in Malaysian Secondary Schools. We do this with the intention of establishing whether these texts have had the capacity to facilitate engagement, inclusion and dialogue amongst ethnically diverse learners, as well as the problematics of locating such texts.

Our main premise of argument is that Literature in English if used gainfully in the Malaysian curriculum can be a significant tool to study the realities of Malaysian nationhood and its constructions of racial politics, and ultimately, an effective tool to forge nation building. National unity is after all a fundamental aspect of the Malaysian national education policy, dating from as far back as the Barnes and Fenn Wu report with their aspirations for a common and united Malayan identity in education and woven together in the Razak Report of 1956 which saw the transformation of the education system in accordance to the aspirations of a budding nation, culminating in the Education Ordinance of 1957 (Brown, 2007: 320). Unity is also mentioned as one of the key aims of Malaysian education, the Malaysian Education Blueprint 2013-2025 as ascertained in the following extract from the document:

There is no better predictor of a nation's future than what is currently happening in its classrooms ... Education is also fundamental to nation building and unity. It provides individuals with the opportunity to improve their lives, become successful members of the community and active contributors to national development. Through interacting with individuals from a range of socio-economic, religious and ethnic backgrounds - and learning to understand, accept and embrace differences - a shared set of experiences and aspirations for Malaysia's future 
can be built. It is through these shared experiences and aspirations that a common national identity and unity is fostered.

(Malaysian Education Blueprint 2013-2025, 2013: E-1)

While the passage firmly places education as a harbinger of national unity, the apparent understanding of the way in which unity can be achieved is through mediated activities such as the Ministry derived Student Integration plan for Unity which involves co-curricular inter-school interactions (Malaysian Education Blueprint 2013-2025, 2013: E-9). The same blueprint also identifies national unity as one of the five aspirations of the Malaysian Education system, as achieved through "an education system that gives children shared values and experiences by embracing diversity" (Malaysian Education Blueprint 2013-2025, 2013: E-9). However, tangible tools for engendering these qualities are largely invisible.

Contini and Maturo (2011) posit that subjects like history, geography, literature, mathematics and others which are also known as scholastic subjects create an opportunity of intercultural formation. For instance history in an intercultural setting should not reinstate ethnocentric views, while arts and music should project the relation between different cultures thus respecting diversity. On the other hand, subjects like Geography show the progression from local context to world view while religious subjects allow direct and concrete opportunity to understand practises and symbols from diverse religious groups. Civics as a scholastic subject provides the space to understand the Constitution, human rights, and international institutions. The writers conclude that such forms of intercultural education can become a new curricular space that will have the ability to promote openness, equality, social living together and social cohesion as it provides the space for cultural, linguistic and religious diversity (Contini and Maturo, 2011: 3685-3686).

Even though the subject of Civic education was admittedly introduced in schools in Malaysia on the heels of the racial riots of 1969 with the aim of ameliorating racial conflict and generating inter-ethnic understanding and sensitivity, as Rahimah (1998) rightly avers, the "formulaic nature of the curriculum" has left little impact on its actual foundational aim as it fails to garner students' interest. Even its predecessor moral education appears to follow the same path, and the recent furore raised by the public over the change of format of the paper in the national school leaving examination of 2013 revealed the extent of the formulaic nature of such subjects and the curriculum.

This leads to the question of how to generate inter-ethnic engagement and awareness through the curriculum? As Ong et al. (2010) have argued, the main concern in most Malaysian schools is to generate the principles of a highly desired $3 \mathrm{R}$ skills (The three Rs translated as reading, writing and arithmetic), the more fundamental issue of $1 \mathrm{R}$, which they posit as "relationship-building" feature very little in the school environment (Ong et al., 2010). Building and fostering 
relationships are after all the key to the creation of a socially cohesive environment. Our main premise of argument is that literature especially local literature can play an important role in Malaysian Education as it can facilitate inter-cultural engagement to form a platform for "a shared social interpretive community" (Desai, 1997: 175) grounded in dialogue and engagement with ethnic diversity. This can be crucial in facilitating inter-ethnic understanding that might never be encountered directly in local schools, given the rising rate of polarisation recorded in the past few decades in Malaysian schools (Samuel and Khan, 2013; Tan and Sezali, 2015; Raman and Tan, 2015).

Extensive research has been done on the importance of using localised literature or multicultural literature to dismantle race and ethnicity stereotypes in diverse classrooms. However, in this quest many scholars caution on text selection and the teaching and learning methodology which are the gateway towards creating cross cultural understanding because the guidelines utilised to select multicultural literature texts for children are predominantly Eurocentric (Naidoo, 1995; McKay, 2001; Jetton and Savage-Davis, 2005). This is a necessary caution as Samuel and Khan (2013) highlight the need to have content relevant to the students as opposed to content alien to them. This is because they posit that foreign books do not assist in the acculturation process of any ethnicity in a multiracial society. The use of foreign content or foreign textbooks was also raised in the Federation of Malaya 1951 report in the contestation on the use of Chinese textbooks which thwarts attempts to unite Malayans of diverse ethnicities particularly that of the Chinese ethnicity in the then Malaya (Samuel and Khan, 2013). Thus it is evident that text selection is a crucial process in the pathway of creating a socially cohesive society amongst diverse ethnicities in a nation such as Malaysia.

In the West, this aspect has already been taken into consideration with the availability of checklists such as Beyond chopsticks and dragons: Selecting Asian-American literature for children by Valerie Ooka Pang, Carolyn Colvin, MyLuong Tran, and Robertta H. Barba (1992), Children's books from other countries by Carl M. Tomlinson (1998), Ten quick ways to analyze children's books for racism and sexism from The Council on Interracial Books for Children (1998) and How to tell the difference: A guide to evaluating children's books for anti-Indian bias by Beverly Slapin, Doris Searle and Rosemary Gonzales (1996). These are important to create an awareness of the need to be inclusive in text selection. However in Malaysia, this sense of inclusiveness in text selection for Malaysian schools does not seem to be emphasised. This matter has actually been raised by Noritah and Washima (2008) who have argued about the need for multiculturalism and inclusiveness in literary texts for Malaysian Primary Schools that focus on Malaysian identity. This absence is also evident in literary texts for Malaysian Secondary Schools as highlighted in this article.

In a multicultural society, the context of the content is crucial in creating an awareness of ideological constructs and their attendant influences on young 
learners (Radhika and Sandhya, 2009; Vengadasamy, 2011; Kalamees-Ruubel and Läänemets, 2012; Ramesh and Talif, 2013). Besides this, using a Eurocentric yardstick is merely a struggle between tokenism and embracing differences (Radhika and Sandhya, 2009). These contentions along with the marginalisation of literatures and declining reading habits have contributed to the lack of communication which can be a contributing factor to social discord in a pluralistic society (Kalamees-Ruubel and Läänemets, 2012). Such arguments underscore the ways in which literature is an important communicator of signifiers of ethnic identity as well as inter-ethnic understanding and misunderstanding, depending on the sensitivity given to text selection, the role of text selection and the syllabi. What then of the scene in Malaysia? How much space has local literature been given in mainstream education?

\section{LOCAL LITERATURE TEXTS IN THE ENGLISH LANGUAGE CURRICULUM IN MALAYSIAN SECONDARY SCHOOLS}

The teaching and learning of literature in English in the context of Malaysian education has traversed many pathways since independence. In the 1960s and 1970s, it nestled at the core of the English language curriculum, and was made up of a corpus of largely canonical and unabridged texts. The majority of the texts originated from Britain, featuring William Shakespeare, Charles Dickens and Jane Austen, amongst others. Also included in the list were a number of texts from France and America, such as Little women by American writer Louisa May Alcott and Around the world in eighty days by French writer Jules Verne. On the whole, the selection of texts did not reflect the issue of inter-ethnic engagement, with the exception of The merchant of Venice - Shakespeare (with the Jewish character Shylock vilified), Around the world in eighty days (with its plot sequence that traverses the globe, Britain, America, Egypt, Japan, Bombay, Hong Kong) and Robinson Crusoe with the relationship between the protagonist and the Caribbean character, Friday. However, the issues in these are marginal to the narrative development and for the most part, favour western characters. While in a postcolonial context these can be discussed for elements of power and submission, of cross cultural encounters and the creation of hierarchies of racial and cultural identity, nevertheless these did not bring the Asian or Malaysian point of view into the classroom, nor could they successfully engender interethnic engagement through reading these texts.

In 1970, with the change in education policy that saw the decentring of English and the subsequent establishment of Bahasa Malaysia as the official medium of instruction, literature was relegated to the confines of reading programs that had the main aim of developing language skills. One of the earliest reading programs to be introduced in the secondary schools after the change in the medium of instruction was the English Language Reading Programme 
(ELRP) which was implemented in 1983 (Edwin, 1993; Ganakumaran, 2003; Too, 2004). Schools received more than 200 graded books with vocabulary lists and grammar items for upper and lower secondary schools. The target was to ensure all learners read 100 books in 3 years. However, after 7 years, ELRP was replaced with a new programme called The Class Reader Programme (CRP).

The replacement was attributed to the lack of structure in ELRP to improve English. As such CRP took over and its implementation was done as part of the New Integrated Secondary School Curriculum (KBSM) in 1993 (Ganakumaran, 2003; Raj and Hunt, 1990). The reading list consisted of 129 books and out of these, there were a considerable number of local texts such as Malaysian tales by Adibah Amin, The quarrelsome couple by Jessie Wee, Pak Belalang by Ranjit Singh, The iron box by Wong Hon Loong, The adventures of Malim Deman by Suraya Sulyman and Ramasamy and The mystery of the strange sounds by Hyacinth Gaudart, to name but a few (Ganakumaran, 2003; Raj and Hunt, 1990). Also significant was the considerable presence of various ethnicities amongst the authors and consequently the content of some of these texts. However, this programme was short-lived and a factor attributed to its demise was that the CRP failed to meet its set objectives due to the lack of training provided to teachers as well as the absence of any form of assessment (Ganakumaran, 2003; Raj and Hunt, 1990).

In 1999 the Ministry of Education made changes to the English Language Teaching policy, which facilitated the introduction of the Literature Component, which was to be incorporated in the English Language Syllabus. Unlike the previous Literature/Reading programmes, the Literature Component was tested in public examinations such as the Penilaian Menengah Rendah (PMR) which was previously known as the Malaysian Lower Certificate of Education and Sijil Pelajaran Malaysia (SPM) which was previously known in English as the Malaysian Certificate of Education. The genres taught included poems, short stories, drama and novel. While most of the texts were originally written in English, some were English translations of texts originally written in Malay. Our focus in this paper is on the translated versions as this paper discusses the role of the texts in the English language syllabus and the repercussions on inter-ethnic understanding. As such, aspects of methods and theories of translation and arguments of discrepancies, while arguably significant, are not conducive for the scope of this paper. We also posit that some translated texts may be necessary for inclusion if there is a dearth of texts on a particular community or if these are significant to render the significant experience of a particular ethnic community. For instance, translated texts from other languages/ethnicities namely Mandarin, Tamil, Iban, Melanau, Senoi, Temiar, to name just a few, have thus far not been included in the selection process of texts for the Literature in English Component. Such an inclusion could very well enable an insight into the diverse ethnicities and cultures in Malaysia thus creating a pathway to inter-ethnic engagement. Such an inclusion must be 
encouraged as it is not possible to find one single text with multiple representations of Malaysia's ethnic diversity and cultures.

The first three genres namely poems, short stories, drama are taught in all the states. However the novels are taught in specific zones at the secondary school level to ensure some form of fairness of distribution for local publishers involved in the endeavour. These zones (territorial demarcation) comprised three regions namely Zone 1 which constituted the states of Perlis, Kedah, Pulau Pinang, Perak and Kelantan, Zone 2 which included the states of Selangor, Negeri Sembilan, Melaka, the Federal Territory of Kuala Lumpur and the Federal Territory of Putrajaya, and Zone 3 which comprised Johor, Pahang, Terengganu, Sabah, Sarawak and the Federal Territory of Labuan. Although these demarcations are set, students are allowed to answer based on any of the novels in the prescribed list.

The texts used in the first cycle (2001-2010) (see Appendix 1) reveal a fair number of local content and a diverse representation of authors from different ethnic communities. Out of 25 texts, there were 8 local titles and 17 foreign texts. Of these, there were three poems, being The dead crow by A. Samad Said, Si Tenggang's homecoming by Muhammad Haji Salleh and Monsoon history by Shirley Lim; three short stories, i.e. The pencil by Ali Majod, How Dalat got its name by Heidi Munan and Of bunga telur and Bally shoes by Che Husna Azhari; and two novels, Jungle of hope by Keris Mas which are only taught in the states of Johor, Pahang, Terengganu, Sabah, Sarawak and the Federal Territory of Labuan while The return by K. S. Maniam is only taught in Perlis, Kedah, Pulau Pinang, Perak and Kelantan.

However, the second cycle of texts (see Appendix 2) introduced in 2011 was a stark contrast as local content was relegated to the margins yet again, in what can only be described as almost Janus faced as the number of local texts was reduced to five while the number of foreign texts increased to 20 . Of the five local texts in the second cycle (2011-2020), four, being respectively the poems Heir conditioning by M. Shanmughalingam, A fighter's line by Marzuki Ali, In the midst of hardship by Latiff Mohidin, Are you still playing your flute by Zurinah Hassan are taught in all Malaysian secondary schools. The local novel The curse by Lee Su Ann however is only taught in the states of Johor, Pahang, Terengganu, Sabah, Sarawak and the Federal Territory of Labuan.

Before the 10 year period was due, the texts in the second cycle were replaced and the third cycle (see Appendix 3), was introduced in 2015. Texts in this cycle were introduced in stages. New texts were introduced for Form 1 and Form 4 students in 2015 whilst Form 2 and Form 5 students received the new titles in 2016. The Form 3 students will at the moment use the text from the second cycle (see Appendix 2) until a new text is assigned to them in 2017. In Form One, a total of four texts were introduced being respectively two poems and three novels (one novel for each Zone). In Form Four, the prescribed texts include two poems, two prose and one play which are taught in 2015. In 2016, 
Form Two students study two poems and one prose whilst the Form Five students study two poems and three novels (one novel for each Zone). None of the newly introduced texts were from local Malaysian authors.

A bird's eye view of the entire corpus of texts used in the context of the study of Literature in Malaysian education would thus reveal a preliminary expanding and subsequent narrowing of Malaysian spaces in the literature component. Perhaps a core issue is that there is a concerted effort at emphasising standard varieties of English notably British and the American standard varieties especially when it comes to selection of literary text. While this may be deemed as significant within the context of the development of language proficiency, we argue that in lessening the number of local texts, spaces for inter-ethnic understanding and engagement within the classroom are inevitably reduced too. To test out this hypothesis, we conducted an analysis of the content of the local texts in the first and second cycle of texts selected for the Malaysian Secondary schools to ascertain the extent to which they were able to facilitate engagement, inclusion and dialogue amongst ethnically diverse learners. The findings are presented in the ensuing section. The parameters that governed our analysis of the local texts in the first and second cycle of the Literature in English component of the English Language Curriculum were adapted from Jenson's five dimensions of social cohesion.

In the dimensions of social cohesion, Jenson formulated three pairs of binary opposites of the thematics of inter-ethnic relations, being ethnic inclusion and exclusion, homogeneity or diversity as well as conflict or cohesion in the variables of ethnic representation. Our use of the term social cohesion is predicated on Jane Jenson's definition of the very term as drawn from documentation of the Government of Canada's Policy Research Sub-Committee on Social Cohesion, as that of "the ongoing process of developing a community of shared values, shared challenges and equal opportunity within Canada, based on a sense of trust, hope and reciprocity among all Canadians" (Jenson, 1998: 4). The key points here are that of developing a community that is linked by a collective unconscious. This collective unconscious is based on a mutually engaging sentiment of a shared communal identity which recognises and includes its diverse others. Only then can the community foster a sense of belonging. Jenson subsequently develops this thesis on social cohesion by mapping out five dimensions to the concept, each forming a pair of binary opposites, as depicted as follows: 
Table 1: Dimensions of social cohesion

\begin{tabular}{lll}
\hline Belonging & $\ldots \ldots \ldots \ldots \ldots$. & isolation \\
Inclusion & $\ldots \ldots \ldots \ldots \ldots$. & exclusion \\
Participation & $\ldots \ldots \ldots \ldots \ldots .$. & non-involvement \\
Recognition & $\ldots \ldots \ldots \ldots \ldots$. & rejection \\
Legitimacy & $\ldots \ldots \ldots \ldots \ldots$. & illegitimacy \\
\hline
\end{tabular}

Source: Jenson (1998: 16).

The pairs identified above encapsulate the key aspects required to achieve social cohesion, and highlight their binary opposites as indicators of their lack. They reflect a range of relationships that centre on the variables of communal acceptance or denunciation, from the most benign to the most malignant. In the first two parameters that governed our analysis, ethnic inclusion and exclusion as well as homogeneity or diversity, evidence of the presence or absence of the portrayal of characters, cultural artefacts/symbols as well religious beliefs and values from diverse ethnic backgrounds were the main signifiers that framed the investigation, whereas in the third dimension, these were inter-ethnic interaction, engagement, ethnic bias/stereotype as well as overt conflicts. We also included the parameter of general signifiers of the historical reality of the nation as an indication of the text's familiarity to the general Malaysian reader and thus inclusion on the general level. These centred on recognisable historical events as well as everyday Malaysian realities. The ultimate aim of this method of investigation was to ascertain the extent that the literary texts selected for inclusion in the two cycles mentioned reflected the following on a continuum of social cohesion: the authority-defined nation on the one end, the middle ground that promotes social cohesion through inter-ethnic understanding and shared core values and nations of intent located within a specific ethnic consciousness on the other end (see Figure 1). The authority-defined nation according to Shamsul A. B. refers to the bumiputera defined identity which has privileged many aspects of bumiputera culture as the "core" of the Malaysian national identity while recognising, if peripherally, the cultural symbols of other ethnic groups' (Shamsul, 2007: 323). On the other hand, nations of intent refers to "a more 'pluralized' national identity, in which the culture of each ethnic group in Malaysia is accorded a position equal to that of the bumiputera both in terms of cultural and religious status" (Shamsul 2007: 324). The attempt is to strike a balance between these two notions of "Malaysian Identities" and progress towards a socially cohesive Malaysian Identity which adheres to the Malaysian constitution as well as the needs of the diverse ethnicities in Malaysia. 


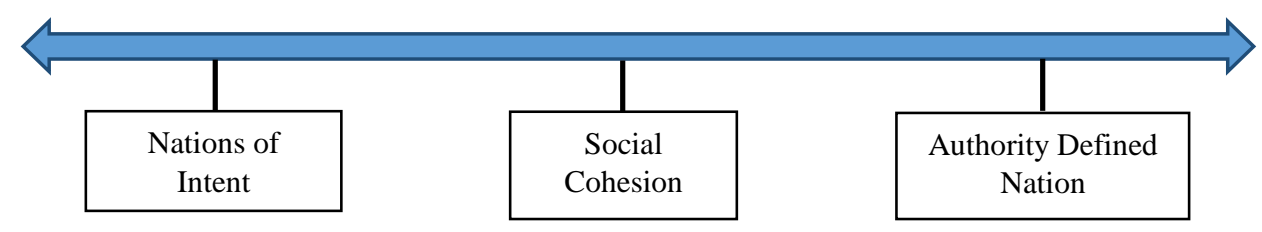

Figure 1: Continuum of social cohesion for Malaysia.

\section{ETHNIC DIVERSITY AND LOCAL TEXTS IN THE LITERATURE IN ENGLISH COMPONENT OF THE ENGLISH LANGUAGE CURRICULUM}

Collectively, the local texts in the first cycle of the Literature in English component of the English Language Curriculum can be said to be significant for their reflection of ethnic diversity as the first cycle contained texts from writers of at least four ethnic communities in Malaysia, thus reflecting elements of Jane Jenson's dimensions of inclusion as well as recognition in terms of ethnic diversity in text selection. However, a closer look at the specific content of each text revealed some interesting details on the dialectics of ethnic relations and implications of social cohesion in the school grounds. We begin with the two novels, before proceeding with the short stories and the poems.

\section{Ethnic Diversity and Local Texts in the First Cycle of the Literature in English Component}

The narrative of the novel, Jungle of hope (Keris Mas, 2000), is, on the whole, predominantly steeped in a literary aesthetics that lean heavily towards the Malay cultural world. A contributing factor to this could very well lie in the fact that the novel is a translated version of the original text written in the Malay language. Coupled with this is the central theme of the wearing away of the fabric of the traditional Malay cultural world, as a result of colonial oppression as well as the arrival of other ethnic communities and its effects on the economic and cultural landscape of the traditional Malay world. In the latter, the text reflects the beginnings of a multi-ethnic community and as such the novel is not homogenous in its ethnic representation. However, the terms of representation of the ethnic other reveals the problematics of early inter-ethnic relations, especially with reference to the ethnic Chinese characters. They are presented as largely predatory profiteers and in a better economic position, illustrious and industrious at the expense of the Malays and their traditional way of life. Ethnic Indians on the other hand, are marginal to the narrative and the sole figure present is portrayed in almost comical and objectified terms. Woven into the narrative thread is also the allusion to the political movement of Kaum Muda, an early 
Malay nationalist movement that emerged to oppose the British and counter the effects of the influx of an immigrant population through advocating steadfastness to the Malay Muslim world. Consequently, the novel abounds in reflections on Islamic religious beliefs and attendant Islamic imagery. In this way, the text, while significant for its depiction of the plight of the Malay community and the intricacies of Malay Muslim culture in the wake of colonial onslaught and its imposed policies reflects sentiments of rejection and illegitimacy in terms of the presence of the ethnic other. The presence of the latter may consequently evoke feelings of marginalisation in readers of the ethnic other.

The return (Maniam, 2000), the only other Malaysian novel in the first cycle, is based on the experiences of the Malaysian Indian community in Malaysia, and particularly draws on the dialectics of alienation and belonging that early Indian settlers experienced as they struggled to adopt a new country. Thus the narrative space abounds with the cultural backdrop of the Indian community which includes reference to numerous Hindu religious symbols, as well as Indian cultural norms and traditions. The novel presents too the diminishing role of communal vernacular education as it is overshadowed by the overarching influence of colonial education and inter-generational rifts that are created as a result. It presents too the intricacies of social stratification amongst the Indian community, drawing out conflicts between the working class and the professional classes. A significant issue that rests at the core of the novel is the problematics of the desire for ownership of land, stretching over two generations and their encounters with unreceptive Town Council officials. However, at intermittent intervals, it reveals too the everyday engagement with a budding multi-ethnic town, with the Chinese shopkeeper, the Chinese mechanic, Kai Pang, the Chinese clerk, Sulaiman, the Malay neighbour, the Malay woman at the marketplace in town and other characters, with names that signify their ethnic markers or simply referred to as Chinese or Malay or Indian. The school grounds is also revealed to be a place where such inter-ethnic engagement takes place, with the protagonist Ravi's Malay and Chinese friends.Thus the novel, while aesthetically Indian at its core, is not solely homogenous in its representation and the terms of engagement with characters of other ethnicities traverse a little further than those found in Jungle of hope. In its depiction of the conflicts faced by the ethnic other, the novel also acts as a counter narrative to that revealed in the novel, Jungle of hope.

Thus while both texts do focus predominantly on one ethnic community, Malay in Jungle of hope and Tamil Malaysians in The return, there are more instances of engagement in The return than in Jungle of hope. Even if Jungle of hope is translated from the original version it does not provide any instance of real engagement with other ethnic communities whereas The return does. Though there is a necessity of including Jungle of hope as a quintessential novel that best captures the experience of the Malay community, the fact remains that it does reflect some stereotypes. 
With regard to the short stories, Of bunga telur and Bally shoes (Che Husna, 2000) is set in a traditional Malay village in the state of Kelantan and centres on a Malay character, Jamal and his efforts to raise funds for his impending wedding. The groom, struggling with finances, decides to replace the traditional wedding door gift to guests in the form of the bunga telor, or hard boiled eggs, with sweets, to the outraged astonishment of his family members. The story ends with the groom realising to his horror that he did not have a pair of decent shoes for his wedding as he had sold his branded Bally shoes to a cousin to procure money for the wedding celebration. Characters are homogenously from the Malay community and consequently, the narrative space too is indelibly stamped with cultural and religious imagery from the Muslim Malay community. The text thus does not reveal any inter-ethnic engagement, though it can be important for providing insights into village life in the East coast of Malaysia.

The second short story The pencil (Ali, 2000) narrates the events in a rural school in Malaysia, with a central conflict that surrounds the theft of a special pencil. The characters have distinctly Malay names as ethnic signifiers, yet the narrative does not dwell much on Malay aesthetics as it draws out the events that follow the theft and the resolution at the end. Engagement with other ethnic communities is absent by virtue of their exclusion from the narrative space, a factor probably due to the setting of the story. However, the story does provide significant insight into the problematics of material possession and conflicts in the classroom, as well as providing a glimpse in the scenario in rural schools as the protagonist of the story, the young boy, Zahid, is described as having bought the special pencil after collecting and selling rubber scraps from the nearby rubber estate. Thus while the text is homogenous in its representation, it does not reveal any sense of illegitimacy in terms of sentiments towards other ethnic communities.

The third local short story in the list, How Dalat got its name (Munan, 2000), is significant for its depiction of village life in East Malaysia, and its native communities often marginalised from the national imaginary. The text focuses on the Melanau community of Sarawak and the plot centres on the conflicts that arise out of the demise of a Melanau village chief and as the events are drawn out, the narrative highlights in the process all the minutiae of Melanau village life, including its rich indigenous cultural norms. Thus, while the text is homogenous in its representation, it is important for its insight into traditional Eastern Malaysian rituals that mainly remain unknown to the other ethnic communities in Malaysia and would thus create awareness amongst diverse learners.

Of the three local poems in the first cycle, two focus on the Malay community and one on the ethnic Chinese. The latter, Monsoon history (Geoklin, 2000), is set along the thematic lines of The return as it draws in the history of the presence of the other predominant ethnic community in Malaysia, the 
Chinese. The poetic voice draws us far back to the Peranakan or Straits Chinese culture, which was predominantly a hybrid interweaving of Chinese and Malay cultural threads. The depiction of the Peranakan couple bears witness to such inter-ethnic engagement, as they are portrayed in the traditional Malay garb of the sarong and partaking in Chinese rituals venerating their ancestors. The poetic voice also alludes to the traditional Malay form of the poem, the pantun, and this together with the rendition of the monsoon season that abounds in detailed sensory imagery reveals a sense of ethnic inclusion that hinges on notions of belonging. The poem would thus stand as a testimony of the bond between the land and its ethnic minority, and could be used as a conduit to facilitate interethnic awareness in the classroom, with reference to the ethnic Chinese. The persona in the poem Si Tenggang's homecoming (Muhammad, 2000) and likewise that of The dead crow (A. Samad, 2000), both speak and refer to the Malay community and the Malay cultural milieu. The first is a retelling of an old Malay folklore that revolves around the tale of an ungrateful son who is cursed and turned into stone by his own mother on account of his treachery. The poem focuses on the moral at the centre of the folktale but transforms it within the context of the Malay who has journeyed far from the country and encountered foreign cultures, yet returns, "still a Malay" at heart. While the central focus is undeniably on the Malay world, the poem is significant for its openness of vision, of the voyages between cultures as much as it is about physical journeys to foreign lands and as such it stands as an apt metaphor for the pathways towards understanding the other. In this way, the poem does not close in on its ethnic self and would appeal to the learners of diverse ethnic backgrounds. The last local poem in the list, The dead crow reads as a universal indictment against poverty, environmental destruction and ends with a reminder to the politicians to plan wisely for the future of the country so that it may sustain itself over generations to come. The poetic voice could thus speak to every learner in the country as it does not close in on any recognisable ethnic markers and instead speaks to the nation, and in particular leaders of the nation.

The selection of the local Malaysian texts in the first cycle thus does reveal the basic dimension of inclusion of ethnic communities and the content of the texts in turn can be seen to oscillate between reflecting dimensions of recognition belonging to legitimacy and isolation to illegitimacy. If these texts were seen in comparison, and taught with a careful methodology centred on raising awareness of early conflicts and the beginnings of a new nation, it would be a pathway towards creating inter-ethnic understanding in the classroom. We could add Graeme Turner's argument to those of Naidoo and McKay explored above, in terms of the need to see literary texts as important platforms for active negotiations of cultural identity that can in turn become sites for lucrative cultural capital to develop cultural literacy skills in students (Turner, 2007). The texts in the first cycle would have allowed for the negotiations of the diverse ethnic identities of students and the honing of inter-cultural awareness in the classroom. 
Unfortunately, these spaces that could have promised inter-cultural dialogue and understanding were reduced significantly in the next cycle of texts. As noted above, the second cycle saw only five local texts, of which four were poems and one a novel. The lessening of the space for understanding ethnic diversity was also magnified by the fact that out of the authors of the poems, three were Malay and one of the ethnic Indian minority, while the author of the novel was ethnic Chinese. The following discussion maps out the extent of recognition of ethnic diversity reflected by the text selection and its attendant implications for interethnic engagement.

\section{Ethnic Diversity and Local Texts in the Second Cycle of the Literature in English Component}

We begin by discussing the novel The curse (Lee, 2010). The text though written by an author from the ethnic Chinese community, as deduced by her name, it is a revisionist rendition of the traditional Malay legend of Mahsuri and focuses on a female Malay protagonist as well as her native community. The opening chapter, set in London, draws a multi-ethnic group of characters, mainly Asian and trains in on the protagonist, a young Malay woman named Azreen and a Malaysian Chinese male character named Julian Ng. However, this is only for a brief moment for we are soon transported into a rural setting in Malaysia particularly a remote village in Langkawi, as Azreen rushes to board a flight home to Malaysia upon receiving news of her adopted sister; Madhuri's, death. The plot revolves around Azreen's investigation of what she believes are suspicious circumstances of Madhuri's death. During the course of her investigation, Azreen uncovers that Madhuri was an abandoned child who was adopted by her parents. She was later forced to marry the village headman and unhappiness led to a forbidden love affair that eventually led to her murder. Interwoven into the plot are strong threads of Malay folklore, including shamanism through the practices of the village medicine man or bomoh and the references to the presence of a female demoness or pontianak. Such references to Malay folklore are significant for their insight into traditional customs and belief systems that may still preside over rural Malay villages. All of these create a sense of alienation and bewilderment for the main character Azreen who does not engage with nor believe the local rural legends. These depictions are thus significant for revealing the widening gyre between the rural and the urban, globalised Malay. In addition, the text is also rich in portraits of everyday realities associated with rural Malay life. The use of Malay proverbial terms and words such as lipas kudung, gaharu, kenduri arwah, ganas, limau kasturi, nasi lemak, songkok, puteri suci, majlis bersanding, doa, ketupat, rendang, kuih, pegaga leaves, syair further accentuates the focus on the Malay community. Apart from these are also the references to cultural artefacts such as drapes with images of the Kaabah, wooden statues from Indonesia, carvings and carpets from the Middle East, traditional instruments 
from the Malay sultanate era and keris, all of which hint on Islamic elements identifiable with the dominant community. It must be stated that as the novel is written by a Malaysian Chinese author, such rich ethnographic details of the Malay community can be seen as a feat of inter-ethnic understanding. However, it does not reveal any instances of engagement with other ethnicities, a fact that could be due to its rural Malay setting. As such, the novel adds to the predominance of the Malay in the syllabus.

The ensuing discussion looks at the three poems introduced in the second cycle. We begin with the three poems by the Malay authors before proceeding with poems by the minority ethnic others. A fighter's Line (Marzuki, 2009) generally speaks of the tenets of nationhood and freedom from foreign domination. The persona is depicted as a war veteran, a freedom fighter, scarred by his experience, both physically and psychologically. The text portrays a general national historical event seemingly when read at surface level without an explicit indicator of the ethnic identity of the persona. Along with thematic threads of patriotism, courage and unity, the poem stands as an evocative lamentation of the persona's perception of a nation now encumbered by lies and deception. It is in the latter that glimpses of leaning toward a particular ethnic community is made evident through references such as "sons of our ancestor" and "heirs of our freedom", alluding to the state-sanctioned view of the Malay community as bumiputera or "sons of the soil" and thus rightful owners and heirs of the land. In this way the poem excludes the contribution of other ethnic communities in its depiction of the fight for independence which may consequently evoke feelings of marginalisation in readers of other ethnic backgrounds.

In the midst of hardship (Latiff, 2009) is a poem written in Bahasa Malaysia in 1978 and translated by Salleh Ben Joned. It portrays a pastoral setting, as it focuses on life that is recognisably in the rural area of Malaysia particularly in the northern or eastern region which is prominent as flood-prone areas. While one might link the depiction of the family venturing out to look for a lost albino buffalo amidst the flood to the indigenous Malay community, the poem does not contain explicit indicators of ethnic identity. Nevertheless the themes highlighted such as being resilient to the adversities faced in life, the importance of family bonding and accepting one's fate relates to everyone thus making this poem a good source of portrayal of everyday reality. The albino buffalo stands as a symbolic representation of hope against despair as the colour white represents purity or hope as well as surrender or despair. Besides this, the buffalo is a common cultural artefact amongst the diverse ethnicities in Malaysia. As such its use in this poem lends itself as a cultural symbol which can be interpreted in any cultural setting. In other words, this poem could be a suitable text to understand village or rural life particularly of the Malay community and as such can facilitate inter-ethnic understanding. 
Are you still playing your flute (Zurinah, 2009) like the previous poem is a translation completed by the poet herself. The setting in this poem too portrays a pastoral setting of life that is recognisably in rural Malaysia. Like the other two poems, it does not contain any explicit indicator of the ethnic identity of the persona or the other figures referred to in the poem. However, the reference to the "slim hollow of the bamboo" of the flute as well as the rice fields are closely connected and draw out the indigenous Malay community. Having said this, the themes in this poem highlight issues such as priorities in life and neglect of one's duties. These are universal themes that reflect portrayal of everyday realities thus applicable to any ethnicities. As such, like In the midst of hardship, this poem could be a suitable text to understand village or rural life particularly of the Malay community and can facilitate inter-ethnic understanding. However, this poem unlike the previous two, has two discrepancies. Firstly, the poet claims that one of the lines was misprinted from the original translation of the poem. The line "in the hazard of you" should actually read "in the hazard of this city" (Zahuren, 2010). Secondly, the last stanza of the poem was omitted in the student's edition; the reason as to why this was done is uncertain (Tan, 2011). Although these discrepancies give a different reading and interpretation than the original version, we opt to analyse the poem as it appears in the students' edition.

This leads us to the fourth local poem in the list; Heir conditioning (Shanmughalingam, 2009), the only poem by the ethnic other. While the author is recognisably of the ethnic Indian community, the poem does not contain any religious nor cultural references related to that particular community. From the point of view of ethnic and cultural inclusion, the poem can be seen as providing a universal viewpoint on environmental issues as a result of accelerated development, which would be relevant to readers regardless of ethnic background. The presence of kinship terms such as "grandma", "granddad" and "grandchild" are similarly devoid of specific ethnic cultural affiliation, and could be seen to point to an English-educated middle class family. The poem thus does not provide any insight into a particular ethnic nor cultural background but instead, portrays issues connected to the everyday reality of Malaysia, in terms of development and its setbacks as well as the generation gap between the older and the younger generations.

The local texts in the second cycle thus remain a stark reflection of a privileging of the point of view of only one ethnic community, and the advent of a form of "symbolic violence", an apt term that Audrey Bryan uses to refer to homogenised curriculum material as it reinforces the otherness and invisibility of ethnic minorities (Bryan, 2009: 298). If left unchecked such narrowing of the spaces of local aesthetics and diversity in the English Language Syllabus that appear to lean heavily towards on exclusion rather than inclusion may lead to a creation of illegitimacy of the ethnic other in the national education imaginary. If spaces are not created for engagement, Malaysian classrooms would eventually become disconnected sites. What would ultimately take root is a lack of 
understanding leading to isolation, rejection and illegitimacy, all the variables at the other end of the spectrum of social cohesion.

\section{Ethnic Diversity and Local Texts in the Third Cycle of the Literature in English Component}

The new texts introduced thus far in the third cycle confirmed the narrowing of spaces for Malaysian Literature in English where none of the texts included were from the Malaysian Literature in English selection. The only Malaysian Literature in English text retained this year is the poem A fighter's line for the Form Three students which is from the second cycle. However this poem as mentioned earlier focuses on a patriotic theme and is identifiably Malay. The other single text that comes close to an Asian text is Tanjung Rhu by Minfong Ho which reminisces the fading Chinese culture among the younger generation in a fast paced world like Singapore. The story does present distinctively Chinese cultural elements. However, as the focus is on the Singaporean Chinese experience, our contention is that it is not the same as the Malaysian Chinese experience, given the differences post-separation from Malaysia in 1965. As such this cycle does not reveal any other Malaysian ethnic community.

The inclusion of only Eurocentric texts confirms privileging of the Western Canon over local texts. This could have been a conscious choice or a subconscious one but one made according to the norm that the English Canon constitutes as the absolute criterion of literary excellence. Terry Eagleton demystifies this notion of great literature or the literary canon as a construct as he argues that "value is a transitive term" meaning "whatever is valued by certain people in specific situations according to a particular criteria and in the light of given purpose, may change in the future and especially so now when arguments have been forwarded in the inability of the canon to accommodate cultural differences" (Eagleton, 2011: 10). Moving closer to home, Malachi Edwin Vethamani and Premalatha Nair (2009) investigated students' perceptions of the various literary components introduced in secondary schools and the various activities carried out in Malaysian classrooms. They conclude that students' needs and cultural background must be considered in text selection. In conclusion, appropriating the English Language to express themselves, enables Malaysian writers to express themselves better and locates this sectional literature as a vital tool to unite the diverse ethnicities in Malaysia. This discussion has been brought forth by many prominent scholars with reference to world writing in English. Amongst these are Frantz Fanon, Raja Rao, Chinua Achebe, Braj Kachru, Ngugi wa Thiong'o to name a few (Quayum, 2003: 184). 


\section{CONCLUSION}

Our main concern in this paper has been primarily the way in which Malaysian literature can facilitate understanding and awareness between diverse classroom communities. The review of the literature texts across the decades has shown that diversity in its Malaysian context has not been a priority. Also, in the case where literature is primarily used in its capacity for developing language skills, interethnic relations may not be a priority. In view of this, an alternative may lie in the incorporation of Malaysian literature for sustainable interethnic engagement in Malaysian schools, as part of a general Malaysian Ethnic Relations subject, to be taught in Malaysian schools. Literature could play a fundamental role in this module, to the aim that the cultural diversity that abounds in the nation may be shared in the classroom in a way that may illuminate the minds of students, instead of being imparted in didactic terms. However, it will not be enough to merely set the texts. In order to foster the latter, classroom activities should focus on enabling students to view literary texts as portals to the diverse cultural worlds that they live amongst and to create an awareness of the possibilities of encountering, knowing and ultimately, understanding the many cultural worlds that exist beyond familiar grounds. The teaching methodology must thus be grounded in critical reading approaches. With this latter, training of teachers as facilitators of inter-ethnic engagement is also crucial. While many may argue that such transformations may be time-consuming and impose additional weights to already overburdened educationists in Malaysian schools, in a nation that is beginning to witness the development of increasingly monocultural school environments and/or the marginalisation of ethnic minorities and their sensitivities, inter-ethnic engagement in schools must be a priority, if the national education is to achieve its aim of promoting national unity.

\section{ACKNOWLEDGEMENTS}

This study was funded by Ministry of Higher Education, Malaysia. Grant name: Long Term Research Grant Scheme (LRGS) / Skim Geran Penyelidikan Jangka Panjang Bottom-Up (LRGS-BU). Grant Number: LRGS/BU/2011/UKM/CMN. 


\section{APPENDIX 1}

List of Texts for Literature in English Component for Malaysian Secondary Schools: First Cycle (2001-2010)

\begin{tabular}{|c|c|c|c|c|c|}
\hline No & Form & Genre & Title & Author & Region \\
\hline 1 & One & Poem & $\begin{array}{c}\text { Life's brief candle } \\
\text { In Selected poems } \\
\text { and short stories: } \\
\text { Form } 1\end{array}$ & William Shakespeare & All \\
\hline 2 & One & Poem & $\begin{array}{c}\text { The dead crow } \\
\text { In Selected poems } \\
\text { and short stories: } \\
\text { Form } 1\end{array}$ & Abdul Samad Said & All \\
\hline 3 & One & Poem & $\begin{array}{l}\text { The lake isle of } \\
\text { innisfree } \\
\text { In Selected poems } \\
\text { and short stories: } \\
\text { Form } 1\end{array}$ & William Butler Yeats & All \\
\hline 4 & One & $\begin{array}{l}\text { Short } \\
\text { story }\end{array}$ & $\begin{array}{c}\text { Of bunga telur and } \\
\text { Bally shoes } \\
\text { In Selected poems } \\
\text { and short stories: } \\
\text { Form } 1\end{array}$ & Che Husna Azahari & All \\
\hline 5 & One & $\begin{array}{l}\text { Short } \\
\text { story }\end{array}$ & $\begin{array}{c}\text { The pencil } \\
\text { In Selected poems } \\
\text { and short stories: } \\
\text { Form } 1\end{array}$ & $\begin{array}{l}\text { Ali Majod } \\
\text { (translation) }\end{array}$ & All \\
\hline 6 & One & $\begin{array}{l}\text { Short } \\
\text { story }\end{array}$ & $\begin{array}{c}\text { How Dalat got its } \\
\text { name } \\
\text { In Selected poems } \\
\text { and short stories: } \\
\text { Form } 1\end{array}$ & Heidi Munan & All \\
\hline 7 & Two & Novel & $\begin{array}{c}\text { The phantom of the } \\
\text { opera }\end{array}$ & $\begin{array}{c}\text { Gaston Leroux } \\
\text { (retold \& translation) }\end{array}$ & $\begin{array}{c}\text { Selangor, } \\
\text { KL/Putrajaya, } \\
\text { Negeri } \\
\text { Sembilan, } \\
\text { Melaka }\end{array}$ \\
\hline 8 & Two & Novel & Potato people & $\begin{array}{l}\text { Angela Wright } \\
\text { (unabridged) }\end{array}$ & $\begin{array}{c}\text { Kedah, } \\
\text { Perlis, } \\
\text { Kelantan, } \\
\text { Penang, Perak }\end{array}$ \\
\hline
\end{tabular}




\begin{tabular}{|c|c|c|c|c|c|}
\hline No & Form & Genre & Title & Author & Region \\
\hline 9 & Two & Novel & Robinson crusoe & $\begin{array}{l}\text { Daniel Defoe } \\
\text { (retold) }\end{array}$ & $\begin{array}{c}\text { Johor, Pahang, } \\
\text { Terengganu, } \\
\text { Sabah, } \\
\text { Sarawak, } \\
\text { Labuan }\end{array}$ \\
\hline 10 & Three & Novel & $\begin{array}{c}\text { Dr Jekyll and } M r \\
\text { Hyde }\end{array}$ & $\begin{array}{l}\text { Robert Louis Stevenson } \\
\text { (retold) }\end{array}$ & $\begin{array}{l}\text { Selangor, } \\
\text { KL/Putrajaya, } \\
\text { Negeri } \\
\text { Sembilan, } \\
\text { Melaka }\end{array}$ \\
\hline 11 & Three & Novel & $\begin{array}{l}\text { The prisoner of } \\
\text { zenda }\end{array}$ & $\begin{array}{l}\text { Anthony Hope Hawkins } \\
\text { (simplified) }\end{array}$ & $\begin{array}{c}\text { Kedah, } \\
\text { Perlis, } \\
\text { Kelantan, } \\
\text { Penang, Perak }\end{array}$ \\
\hline 12 & Three & Novel & Walkabout & $\begin{array}{l}\text { Vance Marshall } \\
\text { (simplified) }\end{array}$ & $\begin{array}{c}\text { Johor, Pahang, } \\
\text { Terengganu, } \\
\text { Sabah, } \\
\text { Sarawak, } \\
\text { Labuan }\end{array}$ \\
\hline 13 & Four & Poem & $\begin{array}{c}\text { Sonnet } 18 \\
\text { In Selected poems } \\
\text { and short stories: } \\
\text { Form } 4\end{array}$ & William Shakespeare & All \\
\hline 14 & Four & Poem & $\begin{array}{c}\text { Si Tenggang's } \\
\text { homecoming } \\
\text { In Selected poems } \\
\text { and short stories: } \\
\text { Form } 4\end{array}$ & Muhammad Haji Salleh & All \\
\hline 15 & Four & Poem & $\begin{array}{c}\text { There's been a } \\
\text { death in the } \\
\text { opposite house } \\
\text { In Selected poems } \\
\text { and short stories: } \\
\text { Form } 4\end{array}$ & Emily Dickinson & All \\
\hline 16 & Four & Poem & $\begin{array}{c}\text { The road not taken } \\
\text { In Selected poems } \\
\text { and short stories: } \\
\text { Form } 4\end{array}$ & Robert Frost & All \\
\hline
\end{tabular}




\begin{tabular}{|c|c|c|c|c|c|}
\hline No & Form & Genre & Title & Author & Region \\
\hline 17 & Four & Poem & $\begin{array}{c}\text { Monsoon history } \\
\text { In Selected poems } \\
\text { and short stories: } \\
\text { Form } 4\end{array}$ & Shirley Geok-Lin Lim & All \\
\hline 18 & Four & Poem & $\begin{array}{c}\text { If } \\
\text { In Selected poems } \\
\text { and short stories: } \\
\text { Form } 4\end{array}$ & Rudyard Kipling & All \\
\hline 19 & Four & $\begin{array}{l}\text { Short } \\
\text { story }\end{array}$ & $\begin{array}{c}\text { The lotus eater } \\
\text { In Selected poems } \\
\text { and short stories: } \\
\text { Form } 4\end{array}$ & Somerset Maugham & All \\
\hline 20 & Four & $\begin{array}{l}\text { Short } \\
\text { story }\end{array}$ & $\begin{array}{c}\text { The necklace } \\
\text { In Selected poems } \\
\text { and short stories: } \\
\text { Form } 4\end{array}$ & Guy de Maupassant & All \\
\hline 21 & Four & $\begin{array}{l}\text { Short } \\
\text { story }\end{array}$ & $\begin{array}{c}\text { The drover's wife } \\
\text { In Selected poems } \\
\text { and short stories: } \\
\text { Form } 4\end{array}$ & Henry Lawson & All \\
\hline 22 & Four & $\begin{array}{l}\text { Short } \\
\text { story }\end{array}$ & $\begin{array}{c}\text { The sound machine } \\
\text { In Selected poems } \\
\text { and short stories: } \\
\text { Form } 4\end{array}$ & Roald Dahl & All \\
\hline 23 & Four & $\begin{array}{l}\text { Short } \\
\text { story }\end{array}$ & $\begin{array}{l}\text { Looking for a rain } \\
\text { god } \\
\text { In Selected poems } \\
\text { and short stories: } \\
\text { Form } 4\end{array}$ & Bessie Head & All \\
\hline 24 & Five & Novel & Jungle of hope & $\begin{array}{c}\text { Keris Mas } \\
\text { (translation \& } \\
\text { unabridged) }\end{array}$ & $\begin{array}{c}\text { Johor, Pahang, } \\
\text { Terengganu, } \\
\text { Sabah, } \\
\text { Sarawak, } \\
\text { Labuan }\end{array}$ \\
\hline 25 & Five & Novel & The return & $\begin{array}{c}\text { K. S. Maniam } \\
\text { (unabridged) }\end{array}$ & $\begin{array}{c}\text { Kedah, } \\
\text { Perlis, } \\
\text { Kelantan, } \\
\text { Penang, Perak }\end{array}$ \\
\hline
\end{tabular}


Shanthini Pillai et al.

\begin{tabular}{|c|c|c|c|c|c|}
\hline No & Form & Genre & Title & Author & Region \\
\hline 26 & Five & Novel & The pearl & $\begin{array}{c}\text { John Steinback } \\
\text { (unabridged) }\end{array}$ & $\begin{array}{c}\text { Selangor, } \\
\text { KL/Putrajaya, } \\
\text { Negeri } \\
\text { Sembilan, } \\
\text { Melaka }\end{array}$ \\
\hline $\begin{array}{l}\text { So } \\
\text { Su } \\
\mathrm{M} \text {. } \\
\mathrm{Ta}\end{array}$ & $\begin{array}{l}\text { ce: } \\
\text { t Pekelil } \\
\text { a Pelajar } \\
\text { an } 2000 .\end{array}$ & $\begin{array}{l}\text { Ikhtisas } \\
\text { Bahasa I }\end{array}$ & $\begin{array}{l}\text { 00 Pelaksa } \\
\text { di Sekolah }\end{array}$ & $\begin{array}{l}\text { Tingken Kesusasteraan } 1 \text { Hingg } \\
\text { Tingkan }\end{array}$ & $\begin{array}{l}\text { a Inggeris dalam } \\
\text { catan 5) Bermula }\end{array}$ \\
\hline
\end{tabular}




\section{APPENDIX 2}

List of Texts for Literature in English Component for Malaysian Secondary Schools: Second Cycle (2010-2014)

\begin{tabular}{|c|c|c|c|c|c|}
\hline No & Form & Genre & Title & Author & Region \\
\hline 1 & One & Poem & $\begin{array}{l}\text { Mr nobody } \\
\text { In A collection of } \\
\text { poems, short } \\
\text { stories and drama: } \\
\text { Form } 1 \text { to form } 3\end{array}$ & Anonymous & All \\
\hline 2 & One & Poem & $\begin{array}{c}\text { The river } \\
\text { In A collection of } \\
\text { poems, short } \\
\text { stories and drama: } \\
\text { Form } 1 \text { to form } 3\end{array}$ & Valerie Bloom & All \\
\hline 3 & One & $\begin{array}{l}\text { Short } \\
\text { story }\end{array}$ & $\begin{array}{l}\text { Flipping fantastic } \\
\text { In A collection of } \\
\text { poems, short } \\
\text { stories and drama: } \\
\text { Form } 1 \text { to form } 3\end{array}$ & James Langford & All \\
\hline 4 & One & Novel & Black beauty & $\begin{array}{l}\text { (Anna Sewell) retold } \\
\text { by L. L. Owens }\end{array}$ & $\begin{array}{l}\text { Kedah, } \\
\text { Perlis, } \\
\text { Kelantan, } \\
\text { Penang, } \\
\text { Perak }\end{array}$ \\
\hline 5 & One & Novel & $\begin{array}{l}\text { Journey to the } \\
\text { centre of the earth }\end{array}$ & $\begin{array}{c}\text { (Jules Verne) retold by } \\
\text { Davis Worth Miller \& } \\
\text { Katherine Mcclean } \\
\text { Brevard }\end{array}$ & $\begin{array}{c}\text { Johor, } \\
\text { Pahang, } \\
\text { Terengganu, } \\
\text { Sabah, } \\
\text { Sarawak, } \\
\text { Labuan }\end{array}$ \\
\hline 6 & One & Novel & $\begin{array}{l}\text { The boscombe } \\
\text { valley mystery }\end{array}$ & Arthur Conan Doyle & $\begin{array}{c}\text { Selangor, } \\
\text { KL/Putrajaya, } \\
\text { Negeri } \\
\text { Sembilan, } \\
\text { Melaka }\end{array}$ \\
\hline 7 & Two & Poem & $\begin{array}{l}\text { Heir conditioning } \\
\text { In A collection of } \\
\text { poems, short } \\
\text { stories and drama: } \\
\text { Form } 1 \text { to form } 3\end{array}$ & M. Shanmughalingam & All \\
\hline
\end{tabular}




\begin{tabular}{|c|c|c|c|c|c|}
\hline No & Form & Genre & Title & Author & Region \\
\hline 8 & Two & Poem & $\begin{array}{c}\text { I wonder } \\
\text { In A collection of } \\
\text { poems, short } \\
\text { stories and drama: } \\
\text { Form } 1 \text { to form } 3\end{array}$ & Jeannie Kirby & All \\
\hline 9 & Two & $\begin{array}{l}\text { Short } \\
\text { story }\end{array}$ & $\begin{array}{c}\text { One is one and all } \\
\text { alone } \\
\text { In A collection of } \\
\text { poems, short } \\
\text { stories and drama: } \\
\text { Form } 1 \text { to form } 3\end{array}$ & Nicholas Fisk & All \\
\hline 10 & Two & Drama & $\begin{array}{l}\text { Rumpelstiltskin } \\
\text { In A collection of } \\
\text { poems, short } \\
\text { stories and drama: } \\
\text { Form } 1 \text { to form } 3\end{array}$ & $\begin{array}{c}\text { Retold by } \\
\text { Angela Lanyon }\end{array}$ & All \\
\hline 11 & Three & Poem & $\begin{array}{l}\text { A fighter's lines } \\
\text { In A collection of } \\
\text { poems, short } \\
\text { stories and drama: } \\
\text { Form } 1 \text { to form } 3\end{array}$ & Marzuki Ali & All \\
\hline 12 & Three & Poem & $\begin{array}{c}\text { Leisure } \\
\text { In A collection of } \\
\text { poems, short } \\
\text { stories and drama: } \\
\text { Form } 1 \text { to form } 3\end{array}$ & William Henry Davies & All \\
\hline 13 & Three & Novel & $\begin{array}{l}\text { The railway } \\
\text { children } \\
\text { In A collection of } \\
\text { poems, short } \\
\text { stories and drama: } \\
\text { Form } 1 \text { to form } 3\end{array}$ & Edith Nesbit & $\begin{array}{l}\text { Kedah, } \\
\text { Perlis, } \\
\text { Kelantan, } \\
\text { Penang, } \\
\text { Perak }\end{array}$ \\
\hline 14 & Three & Novel & How I met myself & David A. Hill & $\begin{array}{l}\text { Selangor, } \\
\text { KL/Putrajaya, } \\
\text { Negeri } \\
\text { Sembilan, } \\
\text { Melaka }\end{array}$ \\
\hline
\end{tabular}




\begin{tabular}{|c|c|c|c|c|c|}
\hline No & Form & Genre & Title & Author & Region \\
\hline 15 & Three & Novel & $\begin{array}{l}\text { Around the world } \\
\text { in } 80 \text { days }\end{array}$ & Jules Verne & $\begin{array}{l}\text { Johor, } \\
\text { Pahang, } \\
\text { Terengganu, } \\
\text { Sabah, } \\
\text { Sarawak, } \\
\text { Labuan }\end{array}$ \\
\hline 16 & Four & Poem & $\begin{array}{l}\text { In the midst of } \\
\text { hardship } \\
\text { In A collection of } \\
\text { poems, short } \\
\text { stories and drama: } \\
\text { Form } 4 \text { \& form } 5\end{array}$ & Latiff Mohidin & All \\
\hline 17 & Four & Poem & $\begin{array}{c}\text { He had such quiet } \\
\text { eyes } \\
\text { In a collection of } \\
\text { poems, short } \\
\text { stories and drama: } \\
\text { Form } 4 \& \text { form } 5\end{array}$ & Bibsy Soenharjo & All \\
\hline 18 & Four & $\begin{array}{l}\text { Short } \\
\text { story }\end{array}$ & $\begin{array}{c}\text { Qwertyuiop } \\
\text { In A collection of } \\
\text { poems, short } \\
\text { stories and drama: } \\
\text { Form } 4 \& \text { form } 5\end{array}$ & Vivien Alcock & All \\
\hline 19 & Four & $\begin{array}{l}\text { Short } \\
\text { story }\end{array}$ & $\begin{array}{l}\text { The fruitcake } \\
\text { special } \\
\text { In A collection of } \\
\text { poems, short } \\
\text { stories and drama: } \\
\text { Form } 4 \text { \& form } 5\end{array}$ & Frank Brennan & All \\
\hline 20 & Four & Drama & $\begin{array}{l}\text { Gulp and gasp } \\
\text { In A collection of } \\
\text { poems, short } \\
\text { stories and drama: } \\
\text { Form } 4 \text { \& form } 5\end{array}$ & John Townsend & All \\
\hline 21 & Five & Poem & $\begin{array}{c}\text { Nature } \\
\text { In A collection of } \\
\text { poems, short } \\
\text { stories and drama: } \\
\text { Form } 4 \& \text { form } 5\end{array}$ & H. D. Carberry & All \\
\hline
\end{tabular}




\begin{tabular}{|c|c|c|c|c|c|}
\hline No & Form & Genre & Title & Author & Region \\
\hline 22 & Five & Poem & $\begin{array}{c}\text { Are you still } \\
\text { playing your flute? } \\
\text { In A collection of } \\
\text { poems, short } \\
\text { stories and drama: } \\
\text { Form } 4 \& \text { form } 5\end{array}$ & Zurinah Hassan & All \\
\hline 23 & Five & Novel & The curse & Lee Su Ann & $\begin{array}{l}\text { Johor, } \\
\text { Pahang, } \\
\text { Terengganu, } \\
\text { Sabah, } \\
\text { Sarawak, } \\
\text { Labuan }\end{array}$ \\
\hline 24 & Five & Novel & Step by wicked step & Anne Fine & $\begin{array}{l}\text { Selangor, } \\
\text { KL/Putrajaya, } \\
\text { Negeri } \\
\text { Sembilan, } \\
\text { Melaka }\end{array}$ \\
\hline 25 & Five & Novel & Catch us if you can & Catherine Macphail & $\begin{array}{l}\text { Kedah, } \\
\text { Perlis, } \\
\text { Kelantan, } \\
\text { Penang, } \\
\text { Perak }\end{array}$ \\
\hline
\end{tabular}

Source:

1. Surat Pekeliling Ikhtisasa Bil.7/2009 Pertukaran Teks Komponen Sastera dalam Mata Pelajaran Bahasa Malaysia dan Bahasa Inggeris (KOMSAS) di Sekolah Menengah (Tingkatan 1 Hingga Tingkatan 5) Bermula Tahun 2010. http://www.moe.gov.my/upload/ galeri_awam/pekeliling/1259137243.pdf

2. Surat Pekeliling Ikhtisasa Bil.12/2010 Pertukaran Teks Komponen Sastera dalam Mata Pelajaran Bahasa Malaysia dan Bahasa Inggeris (KOMSAS) di Sekolah Menengah (Tingkatan 2 dan Tingkatan 5) Bermula Tahun 2011. http://www.moe.gov.my/cms/ upload_files/circularfile/2010/circularfile_file_000758.pdf

3. Surat Pekeliling Ikhtisas Bilangan 13 Tahun 2011 Pertukaran Teks Komponen Sastera dalam Mata Pelajaran Bahasa Malaysia dan Bahasa Inggeris (KOMSAS) di Sekolah Menengah Tingkatan 3 Bermula Tahun 2012. http://www.moe.gov.my/cms/upload_files/circularfile/ 2011/circularfile_file_000951.pdf 
APPENDIX 3

List of Texts for Literature in English Component for Malaysian Secondary Schools: Third Cycle (2015-)

\begin{tabular}{cccccc}
\hline No & Form & Genre & Title & Author & Region \\
\hline 1 & One & Poem & News break & Max Fatchen \\
In Poetry for \\
pleasure selected by \\
Rex Kevin Sadler \\
and Thomas Albert \\
S. Hayllar \\
\end{tabular}




\begin{tabular}{|c|c|c|c|c|c|}
\hline No & Form & Genre & Title & Author & Region \\
\hline 8 & Two & Poem & $\begin{array}{l}\text { What is red? } \\
\text { In Poetry for } \\
\text { pleasure selected by } \\
\text { Rex Kevin Sadler } \\
\text { and Thomas Albert } \\
\text { S. Hayllar }\end{array}$ & Mary O'Neill & All \\
\hline 9 & Two & $\begin{array}{l}\text { Short } \\
\text { story }\end{array}$ & $\begin{array}{c}\text { Cheat! } \\
\text { In Short story arena } \\
\text { edited by Walter } \\
\text { Mcvitty }\end{array}$ & Allan Baillie & All \\
\hline 10 & Two & Drama & $\begin{array}{l}\text { A night out } \\
\text { In One thousand } \\
\text { dollars and other } \\
\text { plays by Oxford } \\
\text { University Press }\end{array}$ & O. Henry & All \\
\hline 11 & Three & Poem & $\begin{array}{c}\text { A fighter's lines } \\
\text { In A collection of } \\
\text { poems, short stories } \\
\text { and drama: Form } 1 \\
\text { to form } 3\end{array}$ & Marzuki Ali & All \\
\hline 12 & Three & Poem & $\begin{array}{c}\text { Leisure } \\
\text { In A collection of } \\
\text { poems, short stories } \\
\text { and drama: Form } 1 \\
\text { to form } 3\end{array}$ & $\begin{array}{l}\text { William Henry } \\
\text { Davies }\end{array}$ & All \\
\hline 13 & Three & Novel & $\begin{array}{l}\text { The railway } \\
\text { children }\end{array}$ & Edith Nesbit & $\begin{array}{c}\text { Kedah, Perlis, } \\
\text { Kelantan, } \\
\text { Penang, Perak }\end{array}$ \\
\hline 14 & Three & Novel & How I met myself & David A. Hill & $\begin{array}{c}\text { Selangor, } \\
\text { KL/Putrajaya, } \\
\text { Negeri } \\
\text { Sembilan, } \\
\text { Melaka }\end{array}$ \\
\hline 15 & Three & Novel & $\begin{array}{l}\text { Around the world in } \\
80 \text { days }\end{array}$ & Jules Verne & $\begin{array}{c}\text { Johor, Pahang, } \\
\text { Terengganu, } \\
\text { Sabah, Sarawak, } \\
\text { Labuan }\end{array}$ \\
\hline
\end{tabular}




\begin{tabular}{|c|c|c|c|c|c|}
\hline No & Form & Genre & Title & Author & Region \\
\hline 16 & Four & Poem & $\begin{array}{c}\text { The living } \\
\text { photograph } \\
\text { In A poison tree: A } \\
\text { poetry collection } \\
\text { selected by Pie } \\
\text { Corbett and Valerie } \\
\text { Bloom }\end{array}$ & Jackie Kay & All \\
\hline 17 & Four & Poem & $\begin{array}{l}\text { The charge of the } \\
\text { light brigade } \\
\text { In A poison tree: A } \\
\text { poetry collection } \\
\text { selected by Pie } \\
\text { Corbett and Valerie } \\
\text { Bloom }\end{array}$ & $\begin{array}{l}\text { Lord Alfred } \\
\text { Tennyson }\end{array}$ & All \\
\hline 18 & Four & $\begin{array}{l}\text { Short } \\
\text { story }\end{array}$ & $\begin{array}{c}\text { Tanjung Rhu } \\
\text { In Leaving no } \\
\text { footprints: Stories } \\
\text { from Asia }\end{array}$ & $\begin{array}{c}\text { Minfong Ho } \\
\text { Retold by Clare West }\end{array}$ & All \\
\hline 19 & Four & $\begin{array}{l}\text { Short } \\
\text { story }\end{array}$ & $\begin{array}{c}\text { Leaving } \\
\text { In Changing the } \\
\text { skies: Stories from } \\
\text { Africa }\end{array}$ & $\begin{array}{l}\text { M. G. Vassanji } \\
\text { Retold by Jennifer } \\
\text { Basset }\end{array}$ & All \\
\hline 20 & Four & Drama & $\begin{array}{l}\text { The right thing to } \\
\text { do } \\
\text { In Five short plays }\end{array}$ & Martyn Ford & All \\
\hline 21 & Five & Poem & $\begin{array}{c}\text { A poison tree } \\
\text { In A poison tree: A } \\
\text { poetry collection } \\
\text { selected by Pie } \\
\text { Corbett and Valerie } \\
\text { Bloom }\end{array}$ & William Blake & All \\
\hline 22 & Five & Poem & $\begin{array}{c}\text { What happened to } \\
\text { Lulu? } \\
\text { In A poison tree: A } \\
\text { poetry collection } \\
\text { selected by Pie } \\
\text { Corbett and Valerie } \\
\text { Bloom }\end{array}$ & Charles Causley & All \\
\hline
\end{tabular}




\begin{tabular}{cccccc}
\hline No & Form & Genre & Title & Author & Region \\
\hline 23 & Five & Novel & Captain nobody & Dean Pitchford & $\begin{array}{c}\text { Johor, Pahang, } \\
\text { Terengganu, } \\
\end{array}$ \\
& & & & & $\begin{array}{c}\text { Sabah, Sarawak, } \\
\text { Labuan }\end{array}$ \\
& & & & & \\
& Five & Novel & Sing to the dawn & Minfong Ho & Selangor, \\
& & & & & KL/Putrajaya, \\
& & & & & Negeri \\
& & & & & Sembilan, \\
25 & Five & Novel & Dear Mr Kilmer & Anne Schraff & Melaka \\
& & & & & Kedah, Perlis, \\
& & & & & Kelantan, \\
& & & & & Penang, Perak \\
\hline
\end{tabular}

Source:

1. Surat Pekeliling Ikhtisas Kementerian Pendidikan Malaysia Bilangan 3 Tahun 2015 Penukaran Teks Komponen Sastera (KOMSAS) dalam Mata Pelajaran Bahasa Inggeris Tingkatan 1 dan 4 Mulai Tahun 2015. http://www.moe.gov.my/cms/upload_files/circularfile/ 2015/circularfile_file_001220.pdf

2. Surat Pekeliling Iktisas Kementerian Pendidikan Malaysia Bil. 11 Tahun 2015 - Penukaran Teks Baharu Komponen Sastera (KOMSAS) dalam Mata Pelajaran Bahasa Inggeris Tingkatan 2 dan Tingkatan 5 Mulai 2016. http://www.moe.gov.my/cms/upload_files/ circularfile/2015/circularfile_file_001347.pdf 


\section{REFERENCES}

Abdul Samad Said. 2000. The dead crow. In Literature in English for upper secondary schools: Selected poems and short stories Form 1, 5. Kuala Lumpur: Ministry of Education Malaysia.

Ali Majood. 2000. The pencil. In Literature in English for upper secondary schools: Selected poems and short stories Form 1, 23-39. Kuala Lumpur: Ministry of Education Malaysia.

Brown, G. K. 2007. Making ethnic citizens: The politics and practice of education in Malaysia. International Journal of Educational Development 27(3): 318-330. http://dx.doi.org/10.1016/j.ijedudev. 2006.12.002.

Bryan, A. 2009. The intersectionality of nationalism and multiculturalism in the Irish curriculum: Teaching against racism? Race Ethnicity and Education 12(3): 297317. http://dx.doi.org/10.1080/13613320903178261.

Che Husna Azahari. 2000. Of bunga telur and Bally shoes. In Literature in English for upper secondary schools: Selected poems and short stories Form 1, 11-21. Kuala Lumpur: Ministry of Education Malaysia.

Contini, R. M. and A. Maturo. 2011. Intercultural education and construction of living together in a plural society: The results of an empiric research. Procedia-Social and Behavioral Sciences 15: 3683-3697. http://dx.doi.org/10.1016/j.sbspro. 2011.04.357.

Desai, L. 1997. Reflections on cultural diversity in literature and in the classroom. In Reading across cultures: Teaching literature in a diverse society, eds. T. Rogers and A. O. Soter, 161-177. New York: Teachers College Press.

Eagleton, T. 2011. Literary theory: An introduction. Anniversary ed. Oxford: Blackwell Publishing Ltd.

Edwin, M. 1993. Teaching literature in English in Malaysian secondary schools. In Teaching literature: A world perspective, eds. C. J. Brumfit and. M. Benton, 44-49. London: Macmillan.

Ganakumaran, S. 2003. Literature programmes in Malaysian schools: A historical overview. In Teaching of literature in ESL/EFL contexts, ed. G. Subramaniam, 27-48. Petaling Jaya: Sasbadi Sdn. Bhd.

Geok-lin, S. L. 2000. Monsoon history. In Literature in English for upper secondary schools: Selected poems and short stories Form 4, 13-15. Kuala Lumpur: Ministry of Education Malaysia.

Ho, M. 2014. Tanjung Rhu. In Leaving no footprint: Stories from Asia, 18-35. Kuala Lumpur: Ministry of Education Malaysia.

Jenson, J. 1998. Mapping social cohesion: The state of Canadian research. Ottawa: Canadian Policy Research Networks Inc.

Jetton, T. L. and E. M. Savage-Davis. 2005. Preservice teachers develop an understanding of diversity issues through multicultural literature. Multicultural Perspectives 7(1): 30-38. http://dx.doi.org/10.1207/ s15327892mcp0701_6.

Kalamees-Ruubel, K. and U. Läänemets. 2012. Teaching literature in and outside of the classroom. Procedia - Social and Behavioral Sciences 45: 216-226. http://dx.doi.org/10.1016/j.sbspro.2012.06.558.

Keris Mas. 2000. Literature in English for upper secondary schools: Jungle of hope. Translated by A. Amin. Kuala Lumpur: Dewan Bahasa dan Pustaka. 
Latiff Mohidin. 2009. In the midst of hardship. Translated by Salleh Ben Joned. In Literature component for secondary schools: A collection of poems, short stories and drama Form 4 \& Form 5, 3. Kuala Lumpur: Ministry of Education Malaysia.

Lee, S. A. 2010. Literature component for secondary school: The curse. Kuala Lumpur: Utusan Publications and Distributors Sdn. Bhd. with the Ministry of Education Malaysia.

Malaysian Education Blueprint 2013-2025. 2013. Preliminary report. Preschool to postsecondary education. Kuala Lumpur: Ministry of Education Malaysia.

Maniam, K. S. 2000. Literature in English for upper secondary schools: The return. Kuala Lumpur: Skoob Books (M) Sdn. Bhd.

Marzuki Ali. 2009. A fighter's lines. In Literature component for secondary schools: A collection of poems, short stories and drama Form 1 to Form 3, 9-10. Kuala Lumpur: Ministry of Education Malaysia.

McKay, S. L. 2001. Literature as content for ESL/EFL. In Teaching English as a second or foreign language, 3rd ed., ed. M. Celce-Murcia, 319-332. Boston: Heinle \& Heinle.

Muhammad Haji Salleh. 2000. Si Tenggang's homecoming. In Literature in English for upper secondary schools: Selected poems and short stories Form 4, 5-7. Kuala Lumpur: Ministry of Education Malaysia.

Munan, H. 2000. How Dalat got its name. In Literature in English for upper secondary schools: Selected poems and short stories Form 1, 41-51. Kuala Lumpur: Ministry of Education Malaysia.

Naidoo, B. 1995. Crossing boundaries through fiction: A personal account. English in Education 29(1): 4-13. http://dx.doi.org/10.1111/j.1754-8845.1995.tb01132.x.

Noritah Omar and Washima Che Dan. 2008. Multiculturalism and Malaysian children's literature in English. The English Teacher XXXVI: 1-19.

Ong, P. L., H. Ting, P. T. Ong and P. H Ong. 2010. 3R, 1R or 3R+ 1R? The teachers' dilemma. Procedia - Social and Behavioral Sciences 7: 191-200. http://dx.doi.org/10.1016/j.sbspro.2010.10.027.

Pang, V. O., C. Colvin, M. Tran and R. H. Barba. 1992. Beyond chopsticks and dragons: Selecting Asian-American literature for children. The Reading Teacher 46(3): 216-224.

Quayum, M. A. 2003. Malaysian literature in English: Challenges and prospects in the new millennium. Silverfish New Writing 3: 179-194.

Radhika, M. and R. Sandhya. 2009. Text in context: The culture and politics of stereotyping in children's books. Wasafiri 24(4): 16-22.

Rahimah Haji Ahmad. 1998. Educational development and reformation in Malaysia: Past, present, and future. Journal of Educational Administration 36(5). Quoted in Brown, 2007: 324.

Raj, D. and B. Hunt. 1990. The Malaysian class reader programme. Reading in a foreign language 6(2): 369-382.

Raman, S. R. and Y. S. Tan. 2015. The development of Chinese education in Malaysia: Problems and challenges. ISEAS Working Paper Series on "The Development of Chinese Education in Malaysia: Problems and Challenges", No. 2. 23 October. https://www.iseas.edu.sg/images/ pdf/WP2015-02.pdf. 
Ramesh Nair and Rosli Talif. 2013. A critical reading of gender construction in Malaysian children's literature. English Today 29(4): 37-44. http://dx.doi.org/10.1017/ S0266078413000400.

Samuel, M. and M. H. Khan. 2013. Construction of nationhood through education in Malaya: Revisiting the Barnes and Fenn-Wu Reports. Asia Pacific Journal of Education 33(3): 249-260. http://dx.doi.org/10. 1080/02188791.2013.786678.

Shamsul Amri Baharuddin. 2007. Ethnic relations module. Kuala Lumpur: Maskh Sdn. Ltd.

Shanmughalingam, M. 2009. Heir conditioning. In Literature component for secondary schools: A collection of poems, short stories and drama Form 4 \& Form 5, 3. Kuala Lumpur: Ministry of Education Malaysia.

Slapin, B., D. Searle and R. Gonzales. 1996. How to tell the difference: A guide to evaluating children's books for anti-Indian bias. Berkeley, California: Oyate.

Surat Pekeliling Ikhtisas Bil.4/2000. KP (BS) 8591/4/Jld.XVI (4). 18 February 2000. Pelaksanaan komponen kesusasteraan Bahasa Inggeris dalam mata pelajaran Bahasa Inggeris di sekolah menengah (Tingkatan 1 hingga Tingkatan 5) bermula tahun 2000. http://www.moe.gov.my/cms/upload_files/circularfile/2000/ circularfile_file_000317.pdf (accessed on 1 February 2016).

Surat Pekeliling Ikhtisas Bil.7/2009. KP (BPSH-SPDK) 201/005/01(26). 25 November 2009. Pertukaran teks komponen sastera dalam mata pelajaran Bahasa Malaysia dan Bahasa Inggeris (KOMSAS) di sekolah menengah (Tingkatan 1 hingga Tingkatan 5) bermula tahun 2010. http://www.moe.gov.my/upload/ galeri_awam/pekeliling/1259137243.pdf (accessed on 1 February 2016).

Surat Pekeliling Ikhtisas Bil.12/2010. KP (BPSH-SPDK) 201/005/01 Jld. 3(4). 14 October 2010. Pertukaran teks komponen sastera dalam mata pelajaran Bahasa Malaysia dan Bahasa Inggeris (KOMSAS) di sekolah menengah (Tingkatan 2 dan Tingkatan 5) bermula tahun 2011. http://www.moe.gov.my/cms/upload _files/circularfile/2010/circularfile_file_000758.pdf (accessed on 1 February 2016).

Surat Pekeliling Ikhtisas Bilangan 13 Tahun 2011. KP (BPSH-SPDK) 201/005/01. Jld. 4(16). 11 November 2011. Pertukaran teks komponen sastera dalam mata pelajaran Bahasa Malaysia dan Bahasa Inggeris (KOMSAS) di sekolah menengah Tingkatan 3 bermula tahun 2012. http://www.moe.gov.my/cms/ upload_files/circularfile/2011/circularfile_file_000951.pdf (accessed on 1 February 2016).

Surat Pekeliling Ikhtisas Kementerian Pendidikan Malaysia Bilangan 3 Tahun 2015. KP/KPPM/6/Jld. 2(10). 5 March 2015. Penukaran teks komponen sastera (KOMSAS) dalam mata pelajaran Bahasa Inggeris Tingkatan 1 dan 4 mulai tahun 2015. http://www.moe.gov.my/cms/upload_files/circularfile/2015/ circularfile_file_001220.pdf (accessed on 1 February 2016).

Surat Pekeliling Iktisas Kementerian Pendidikan Malaysia Bilangan 11 Tahun 2015. KP/KPPM/6/Jld. 2(18). 29 December 2015. Penukaran teks baharu komponen sastera (KOMSAS) dalam mata pelajaran Bahasa Inggeris Tingkatan 2 dan Tingkatan 5 mulai tahun 2016. http://www.moe.gov.my/cms/upload_files/ circularfile/2015/circularfile_file_001347.pdf (accessed on 1 February 2016). 
Tan, C. W. R. 2011. English teachers' network (Poem): Are you still playing your flute? (original Malay version) 4 January 2011. http:// englishteachernet.blogspot.my/2011/01/poem-are-you-still-playing-your-flute .html (accessed on 1 February 2016).

Tan, Y. S. and Sezali Mat Darit. 2015. The emergence and widening of ethnic divide in the Malaysian educational system. Petaling Jaya: SIRD.

The Council of Interracial Books for Children. 1998. Ten quick ways to analyze children's books for racism and sexism. Sacremento, CA: California Department State of Education.

Tomlinson, C. M. 1998. Children's books from other countries. Lanham: The Scarecrow Press Inc.

Too, W. K. 2004. Young adult literature: An alternative genre in the classroom reading list. The English Teacher 35: 41-59.

Turner, G. 2007. Cultural literacies, critical literacies, and the English school curriculum in Australia. International Journal of Cultural Studies 10(1): 105-114. http://dx.doi.org/10.1177/1367877907073905.

Vengadasamy, R. 2011. Metaphors as ideological constructs for identity in Malaysian short stories. 3L; language, linguistics and literature. The Southeast Asian Journal of English Language Studies 17(special issue): 99-107.

Vethamani, M. E. and P. Nair. 2009. Literacy development through the incorporation of literature in language education for Malaysian secondary school students. Indonesian JELT 5(2): 72-86.

Zahuren. 2010. Welcome all English teachers around Malaysia: Are you still playing flute? 22 October 2010. https://zahuren.wordpress.com/poems/are-you-stillplaying-flute/ (accessed on 1 February 2016).

Zurinah Hassan. 2009. Are you still playing your flute? In Literature component for secondary schools: A collection of poems, short stories and drama Form 4 \& form 5, 6. Kuala Lumpur: Ministry of Education Malaysia. 